\title{
The OSTEnFeld Farm at THE OPEN-AIR MUSEUM; Aspects of THE ROLE OF FolK Museums in CONFLiCTS OF National Heritage
}

\author{
Mette Skougaard
}

The founder of the Danish Folk Museum and the Open-Air Museum, Bernhard Olsen, took a special interest in former Danish provinces; Scandinavian areas lost to Sweden in the 17th century, and Schleswig lost to Prussia in 1864. This paper examines the efforts made by Bernhard Olsen to obtain a farm house from the village of Ostenfeld in Schleswig for the Open Air Museum, and the struggle between the Danish and the German elements in the attempt to define the national and cultural heritage of the region. These nationalistic intentions are seen in relation to the choice of exhibits and exhibition language in the new folk museums of the period.

The Danish folk museum in Copenhagen was opened to the public in 1885 by Bernhard Olsen. Born in 1836, he became among other things director of the Tivoli Gardens amusement park in Copenhagen, an illustrator, and journalist for popular magazines. After only a few years he was able to expand the new museum adding an open-air department, which moved to Lyngby, north of Copenhagen, in 1901. These initiatives on the part of Bernhard Olsen introduced a great museological novelty into Denmark. This, however, was certainly no isolated Danish phenomenon; the Folk Museum was founded in what one may call the epoch of the museums of cultural history in Europe in the second half of the 19th century, and as such it is typical of its time.

Bernhard Olsen's folk museum was to be a popular museum covering the period from the middle of the 17th to the middle of the 19th century. In his own words, its aim was

to give a picturesque and understandable image of our folk and provincial peculiarities, it should preserve the memory of former days, of the ways of life and thinking of our people in those times. By means of an understandable and captivating presen- 
tation it was to show, how our national characteristics have been formed by the climate and the nature of our country under the continuous influence of European culture.

Here we find a whole new approach to the definition of the function and working areas of museums compared to the established museums of the period. For the first time, the folk culture of the last centuries came into focus, and at the same time the new museums tried to appeal to broader groups within the population.

With what intentions was folk culture shown at the new museums? If you visited the Open-Air Museum in 1901 in order to see Danish peasant culture, you would be in for a surprise. At this time, the museum consisted of four old, furnished farmhouses. But they were not from the actual Danish area. Two of them originated from the former Danish provinces in southern Sweden, and one came from the province Schleswig, which was lost to Germany in 1864. According to the guide book, the buildings at the museum were intended to illustrate the evolution of the house from the type with its roots in antiquity to the fully developed farmhouse. The museum would show the major categories in this evolution, the criteria for classification being primarily the way the interior of a building was arranged in relation to its occupants, both man and beast, and the position and type of the hearth.

The first link in Bernhard Olsen's evolutionary sequence was a farmstead from Ostenfeld in South Schleswig, which he classified as an antique house type. The absence of a chimney and the custom of man and beast living in the same room was considered a relic from prehistoric times.
The second link of the evolutionary sequence was seen as a representative of the medieval stage.

The third phase was represented by a farmhouse from southern Sweden in which the cattle no longer sheltered under the same roof as the farmer.

The fourth phase in the sequence was believed to represent the fully developed farmhouse, found in the southern part of Scandinavia, where the farm was clearly divided into heated and unheated buildings according to their function. (Michelsen 1973:9-24, Michelsen 1966: 227244).

In fact, this evolutionary development was well suited to showing the visitor farms from areas which had previously belonged to Denmark: Scandinavian provinces lost in the 17th century, Schleswig lost as recently as 1864, following a deeply traumatic war against Prussia and Austria, in which Bernhard Olsen himself at 28 years of age served as an officer in the Danish army.

The patriotic intentions were not secondary, quite the opposite, in fact the national sentiment was clearly formulated by Bernhard Olsen as one of the basic principles for his museum:

It is important for me to make clear what has been my main idea with the museum in the city (the Folk Museum) and the museum at Folevad (the Open-Air Museum) from the moment that I first took it upon myself to create them. The archaeological museum of pre-history has ... regarded the lost countries across the Sound as absolutely foreign. After the loss of Schleswig this area also received the same treatment, and like the Scanian provinces, it has slipped out of the museum's focal area ... The result is sad. We have made ourselves guilty of a 
kind of surrender of the national community. My intention with the museums was to remedy the neglected and the distorted, and in the choice of the buildings at Lyngby (the Open-Air Museum) I have not sought to find only the thread in the evolution of the house from open hearth to the brick-built chimney. They have been chosen from the lost provinces, not only because the most primitive types were found there, but because our young people must be taught about all that once belonged to Denmark, in order to fix the memory of what has been lost, and pave the way for a spiritual reassembling of what has been dispersed. This is the only kind of reconquest, I can see. (Letter from Bernhard Olsen to Emil Hannover 23.7.1906. Rasmussen 1993:37).

\section{FOLK CULTURE AND MUSEUMS IN A BORDER REGION}

This patriotic attitude was not an isolated phenomenon, it was not unique to Bernhard Olsen, but applied to all the founders of the contemporary Scandinavian folk museums. They were above all determined to appeal to the people of their countries and foster patriotic feelings, and again, they were not unique in their societies. This is a period, where nationalism was encouraged by many states throughout Europe.

In this process, there was a tendency to make certain provinces especially representative of what was seen as the old, traditional cultural values of the country, thereby regarding them as being particularly "national». Dalarna in Sweden is a classic example. Schleswig, the border region between Germany and Denmark, another, and in this area we find in addition different national interpretations of the traditional cultures, since it has been populated by Danes as well as by Frisians and Germans.

The Ostenfeld village, from where Bernhard Olsen's farm originated, is located in the southern part of Schleswig. At the time when Bernhard Olsen obtained the farm, the war against Prussia and Austria in 1864 was still fresh in the memory. All Schleswig had been conquered by Prussia, but under foreign rule there was still a strong hope amongst the Danish part of the population that they would once again be united with the old country in the north.

And in Denmark at this time, very special feelings were associated with everything from Schleswig. Thus, Bernhard Olsen could rely on a very positive attitude in broad circles of the population towards the idea of including a building from Schleswig in his museum. This is also the background to an important private donation, that made the purchase and the moving of the old farm possible.

It was no coincidence that Bernhard Olsen should choose a farm house from the village of Ostenfeld for his museum. This village had already for many years been regarded as an especially «altertümlich" and ethnologically interesting area, among other things because of the oldfashioned costumes, building and furnishing style found here. As early as in 1897 , Bernhard Olsen had obtained wall panels from the farm of Peter Heldt in Ostenfeld. The same year, he started negotiations to buy the whole farm. He visited the farm in January 1898, and had the building measured and drawn. However, before the transaction was completed, a group of citizens from Husum, headed by the mayor of Husum, bought the building in 
order to preserve it in the area. It was then moved to the city of Husum, where it was re-erected as a small open-air museum.

Bernhard Olsen then had to start looking for another building and returned to Ostenfeld in July 1899, where he succeded in obtaining another suitable farmhouse for his museum. A group of Germans tried to persuade the farmer to cancel the deal in order to prevent the building being moved to Denmark. According to tradition at the museum, it was the photograph of the solemn handshake between buyer and seller, that was decisive. The Ostenfeld farm was then moved and re-erected at the Open-Air Museum, where it was presented to the public in 1901. (Michelsen 1976:11-19).

The heated atmosphere shows in the correspondence between Bernhard Olsen and the local school teacher in Ostenfeld, Otto Thiesen, who had taken it upon himself to be Olsen's contact and helper in the area. Why he did this, we do not know exactly, but according to his letters, his cooperation with the Danes led to spite of various kinds from the local authorities. Among other things, he lost his post as chairman in the local savings bank, which was economically important to him and his family. He writes desperately to Bernhard Olsen that all their communication must be kept strictly confidential,

...so muss ich bitten, strenge Verschwiegenheit über dieselbe zu bewahren. Sie würden nur Öl ins Feuer gisten, ja ich könnte dadurch nur schwer geschädigt werden». (Letter from Otto Thiesen to Bernhard Olsen, 31.12.1899).

It is interesting to follow the arguments brought forward to establish the national affiliation in this area. The Danes as well as the Germans imagined a clear-cut Danish-German cultural confrontation, and both sides use the language, the names and the building styles in their argumentation. Bernhard Olsen writes:

Already in the 11th century, the Ostenfeld area was called the Danish side of the river Trene, a name it kept until our century. ...

In the middle ages, in the 13th and 14th century, people from the Ditmarshes and Frisians ... mixed with the Danes in Ostenfeld. They introduced the Low German language and the Saxon building style (which displaced the Danish). However, the personal names in a tax register from 1438 show, that the immigrants were a minority.

The Danish names, according to Olsen, are predominant, and "there are only very few German names». The same goes for the place names. The barrows, the hills, and the fields of the villages, he says, have mostly Danish names, and the name of Ostenfeld itself is of Danish origin, derived from "Østerfjold", (i.e. the Fjold east of Husum) and is similar to the names of the localities in the neighbourhood such as Højfjold, Fjold and Arnfjold.

While Low German has been spoken in this area for centuries in schools and churches, High German has only been spoken in the last two centuries, and anyhow, Danish has been kept up tenaciously in the villages around here. The fact that Ostenfeld was situated between areas of Frisian and Low German, however, made it difficult for our language to survive, and it has now succumbed in everyday talk.

Nevertheless, Bernhard Olsen mentions as documentation that a visitor, J. Ulrich, as 
late as 1830 overheard women from Ostenfeld at a marketplace in the city of Friedrichsstadt speaking Danish to each other, and to a German ear, he says,

the Low German spoken in Ostenfeld has always sounded particularly strange. (Olsen 1898:114115).

The German version of the story is quite different. It was presented by Magnus
Voss, a school teacher in Husum and the historian of Ostenfeld. He was the one who took the initiative to buy and rebuild Peter Heldt's farm in Husum. According to him, especially in Ostenfeld, there had been a Saxon population of farmers as early as the days of Henry I (German king 919-36), and

in the 15th and the 16th century, Ostenfeld was predominantly German, even if a name or two of

Fig. 1. On July 23. 1899, Bernhard Olsen came to terms with the owner of the Ostenfeld-farm, and the transaction was documented with a photograph of the solemn handshake between buyer and seller on the threshold of the building. This photograph supposedly played an important role when a group of Germans tried to make the farmer cancel the deal.

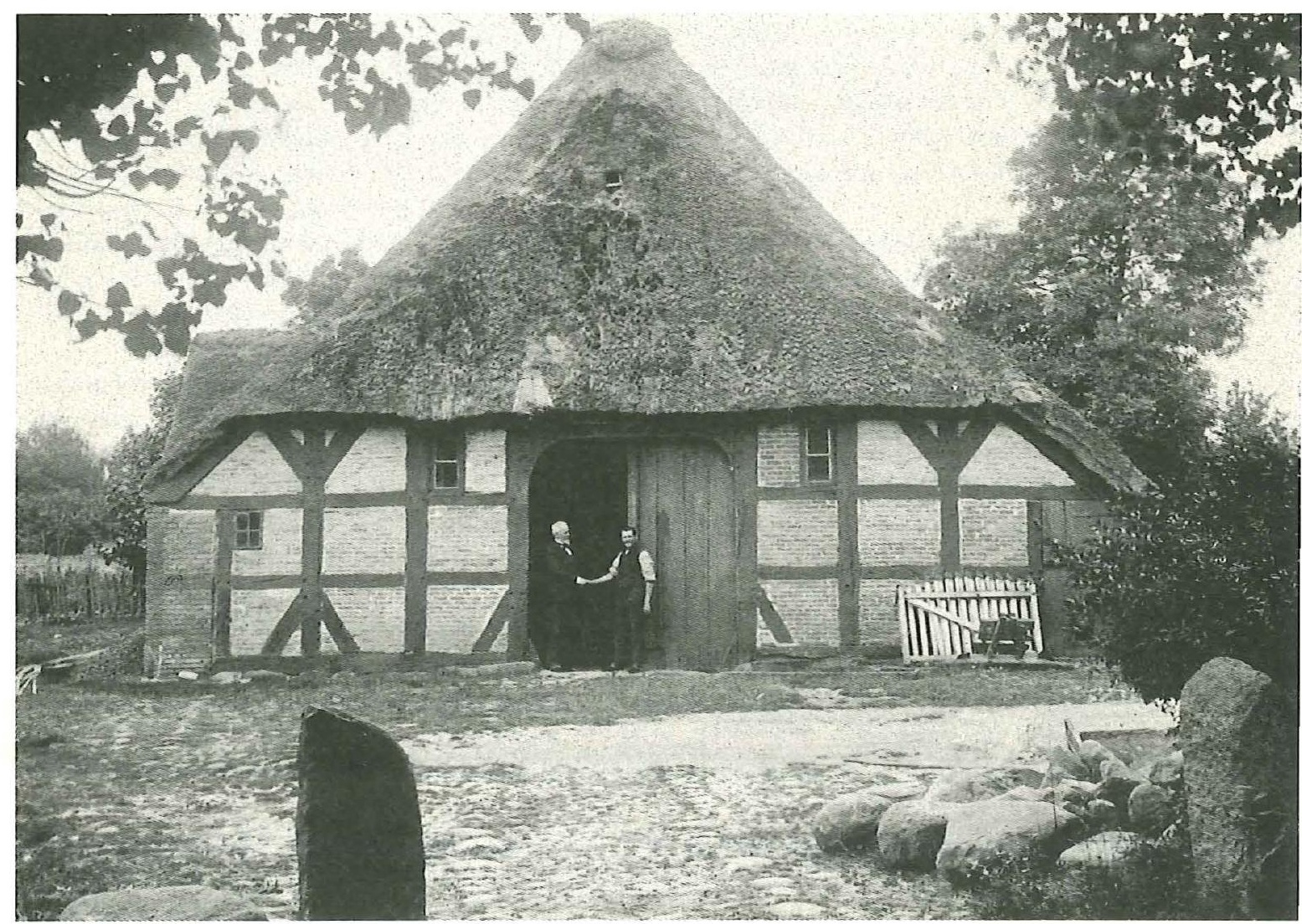


Danish origin has managed to creep into the place names. (Voss 1901:161).

The name of Ostenfeld itself, he claims, has nothing at all to do with the Nordic language, it derives from the "urdeutschen" word "Feld», and was brought here from mother villages in the south.

Der name Viöl oder Feld kann nichts zu tun haben mit dem nordischen "Fjaller» oder "Fjöll», das felsig oder steinig bedeuter; es kann auch nicht mit dem altnordischen Fjöl, gleich "viel» - in der Bedeutung von Menge -zusammenhängen, sondern es ist das urdeutsche Wort «Feld». (Voss 1905: 4).

Voss rejects the case of J. Ulrik, who reported hearing Ostenfeld women at the market in Friedrichstadt speaking Danish to each other, which was mentioned by Bernhard Olsen. According to Voss

the language in Ostenfeld has always and everywhere been the Low Saxon language, and the fact that somebody when spoken to in Danish has answered with a few words in broken Danish is no surprise, you cannot base any conclusions on the heritage of the Ostenfelders on that, nor on the happening with the Ostenfeld women at the market in Friedrichstadt that was mentioned by Bernhard Olsen.» According to Voss "they have spoken Low German to each other, but Danish to the customer. (Voss 1905:5).'

The Ostenfelders are, Voss says, similar to their southern neighbours with respect to extraction and language, and from olden times the Saxon house type has been in use. However, during the 18th century, the seemingly more practical "Dänenhaus» superseded the Saxon house.
150 years ago, almost all farm houses in Ostenfeld were Saxon, little by little the old buildings have been forced to give space to new, Danish buildings. (Voss 1905:62).

\section{NATIONAL MESSAGES AND THE LANGUAGE OF MUSEUMS}

So, the two museum founders - Bernhard Olsen and Magnus Voss - show only too clearly, how they have interpreted the same phenomena in the context of their contemporary political and national beliefs. Very likely, the intentions of spreading these viewpoints to a broader audience played a major role in the form of presentation and communication which developed in the new folk museums. In order to reach a wide section of the population, the folk museum exhibitions had to cater to the educated as well as to the ignorant. They would have to provide a formula for national culture that could be interpreted by a wide section of the population if they really wanted to popularize messages about national culture.

At the established, predominantly archaeological museums of the time, the museum objects were presented according to typological, chronological and other systematic principles, based on an analytical approach to the artifact and on the question of material authenticity.

The classical museum can be illustrated by a drawing from 1846 showing the archaeologist Christian Jürgensen Thomsen, guiding people around the Museum of Nordic Antiquities, later to become the Danish National Museum in Copenhagen. Thomsen's museum is, as formulated by Bjarne Stoklund, "a collection of systematically arranged artifacts packed in 
FOLK MUSEUMS IN CONFLICTS OF NATIONAL HERITAGE

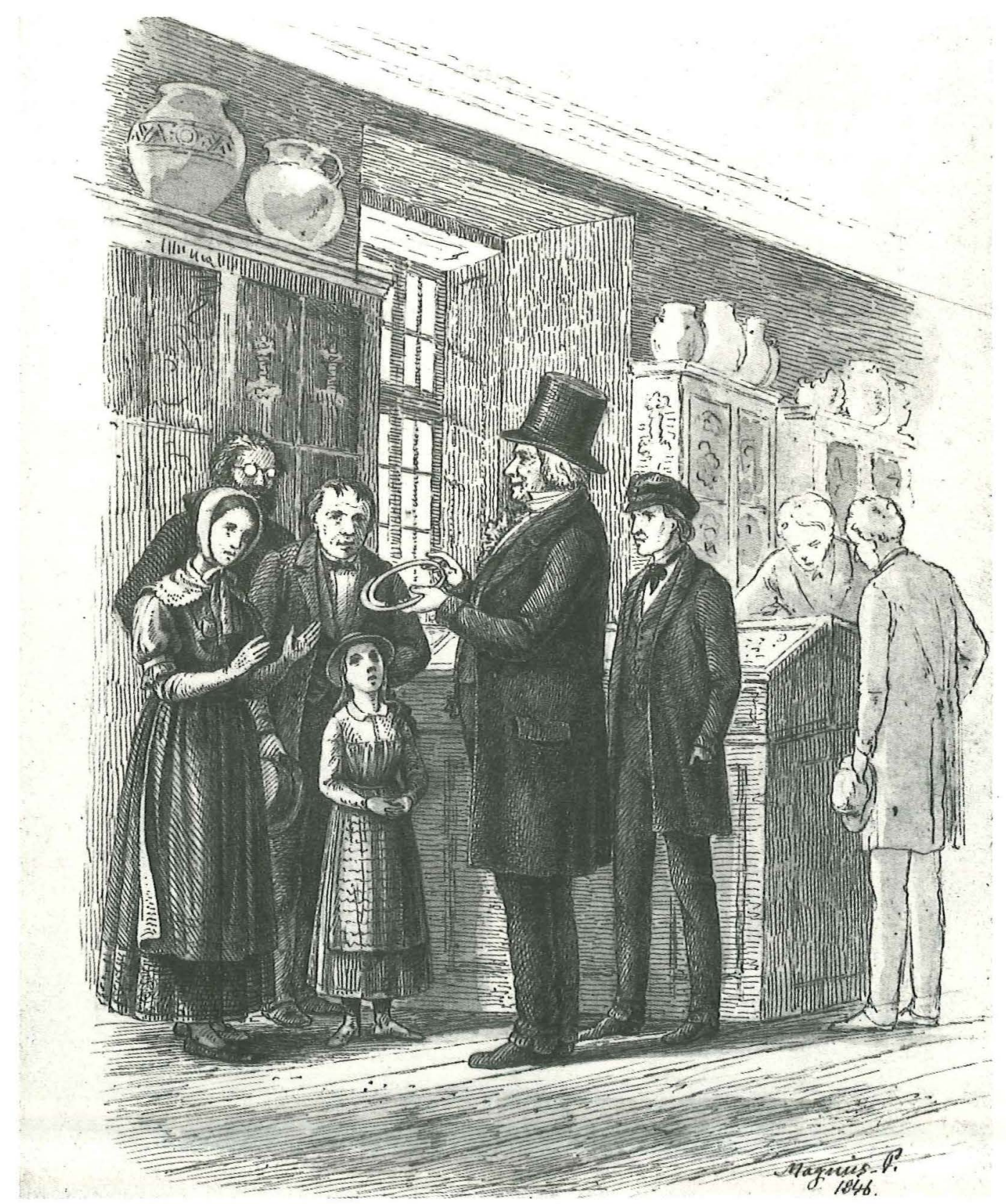

Fig. 2. The archaeologist Chr. Jirrgensen Thomsen presenting the collections to visitors to the Museum of Nordic Antiquities in Copenhagen, 1846. A classical museum of the period with systematically arranged artifacts on display in showcases. Drawing by J. Magnus Petersen. 
METTE SKOUGAard

showcases». (Stoklund 1993:105-107).

In the new folk museums, the collections were replaced by arranged exhibitions, where the aim was to put the objects into a more visually attractive context, adopting the exhibition language that had been developed at the great international exhibitions with roots in the popular panoramas and panoptikons, as well as in the naturalist theatre. Here, the objects are put together and presented in such a way that they speak for themselves within a framework of domestic architecture and national symbols.
In recreating the old rooms and farmhouses, visual authenticity was much more important than the question of material authenticity, everything possible was done to recreate an illusion of the original places, making the visitor feel that he is actually there for a moment, thus making him identify with the life in the old peasant societies. Then it does not matter at all if the furniture is brought together from different houses, or that some of the wall panels, the ceiling or the floor are brand new.

In this manner, the new folk museums

Fig. 3. Folk culture presented by dancers in "folk-costumes» at the Open-Air Museum a widespread and popularized image of Danish traditional culture promoted by many museums all over the country

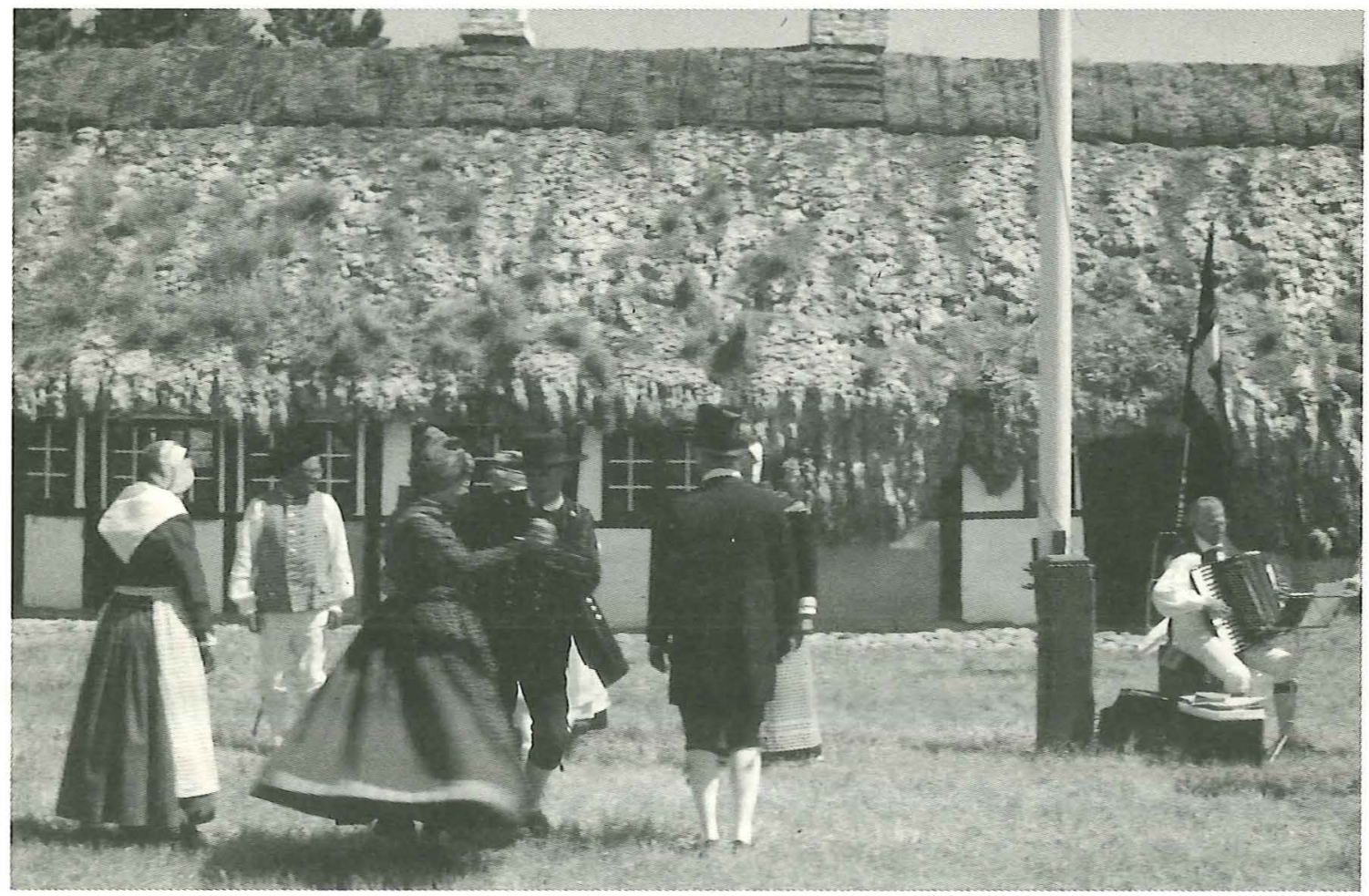


adopted the modern and advanced - and popular - exhibition techniques of their time in order to reach the public. In doing this they have played an active part in the shaping of national symbols, and in integrating these in the public mind. In other words, the musealization of folk culture can be regarded as an important factor in making folk culture an integral part of the national identity established at the time.

However, the new naturalistic museum exhibitions resulted in a heated debate concerning the role and the definition of museums. The criticism was strongly formulated by the archaeologist Sophus Müller who was the director of the Department of Prehistory, the National Museum in Denmark, from 1892-1920. In a famous polemic article from 1897 he insists on the display of object as object alone, with all its wear and tear showing. The artifact should remain a partial reminder of its lost owner, and its organization as display should never exceed that of the collection.

Müller's solution precludes even the slightest sense of imagination. He claims that a museum loses it's status as soon as it encourages any sort of speculation. It becomes something else, some sort of entertainment institution unworthy of the title «Museum». A museum should not recover a historical context for the visitor, and it should not deliver history in the form of a story - which is of course precisely what the folk museums intended. (Müller 1897:683-700).

Seen from the perspective of the question of national identity or heritage, you can use the basic points formulated by Müller to ask: Should the museums serve as archive-storage-exhibition facilities for col- lections of artifacts, or are they institutions that are to help interpret the identity of a nation by letting the visitors identify with more or less - authentic national traditions?

It is now more than 100 years since the folk museums were founded, but these issues are just as relevant and pertinent for the museums of today as they were then.

\section{NOTES}

0 . A shorter version of this article was presented at the 5th SIEF Congress held in Vienna, Austria September 1994.

1. Voss mentions the reported incident from Friedrichstadt twice in his book, and uses much space to repudiate it. For example he writes: «... Wenn aber eine von den Frauen dänisch hat sprechen können, so muss er zufällig eine aus dem nördlicheren Schleswig zugewanderte gewesen sein ... die Provinzial Berichte von 1792 bestätigen, dass im Kirchspiel Ostenfeld damals nicht dänisch geredet worden sein kann ... Ulrik ist also düppiert worden, und diejenigen, die dies Märchen aus seiner Knabenzeit (ulrik was 11 or 12 years of age in 1830) weiter erzählen und es als Beweis für die weit nach Süden reichende Verbreitung der dänischen Sprache ausbeuten wollen, machen sich einer Geschichtsfälschung schuldig. Dabei bleibt es!n. (Voss 1905:5).

\section{REFERENCES}

Michelsen, Peter: Frilandsmuseet. The Danish Museum Village at Sorgenfri. Copenhagen 1973

Michensen, Peter: The Origin and Aim of the OpenAir Museum. Dansk Folkemuseum or Frilandsmuseet. History \& Activities. Odense 1966 Michelsen, Peter: Ostenfeldgarden. Copenhagen 1976 
METTE SKOUGAARD

32 Müller, Sophus: «Museum og Interiør.» Tilskueren, 1897, pp.683-700

Olsen, Bernhard: «Peter Heldts Pesel og dens Indbo." Tidsskrift for Kunstindustri 1898, pp. $112-121$

Rasmussen, Holger: «Hvorfor opstod Folkemuseet.» Nordisk Museologi 1993, 2, pp. 28-39

Voss, Magnus: Chronik der Kirchengemeinde Ostenfeld. Husum 1905

Voss, Magnus: "Das ostenfelder Bauernhaus in Husum». Niedersachsen VI Jahrgang, Nr. 10, 1901

Stoklund, Bjarne: «International Exhibitions and the New Museum Concept in the Latter Half of the Nineteenth Century.» Ethnologia Scandinavica vol. 23, 1993, pp.105-107

Mette Skougaard, Historian and Ethnologist, Curator at The National Museum of Denmark, Department of Modern History.

Adr: The National Museum, Nyere Tid, Brede,

DK-2800 Lyngby

Fax $+45-33473317$.

e-mail:NT-MS@Brede.natmus.min.dk 